\title{
Assessment of the yield loss imparted by Orobanche aegyptiaca in tomato in Pakistan
}

\author{
TANVEER AHMAD ${ }^{1}$, BILAL AHMAD ${ }^{2}$, RANA M. SABIR TARIQ ${ }^{3}$, \\ SYED M. ZIA-UL-HASSAN ${ }^{2}$ and ZAHOOR AHMAD ${ }^{4}$ \\ ${ }^{1}$ Department of Horticulture, Ghazi University, DG Khan, 32200, Pakistan \\ ${ }^{2}$ Institute of Horticultural Sciences, University of Agriculture, Faisalabad, 38040, Pakistan \\ ${ }^{3}$ Department of Plant Pathology, University of Agriculture, Faisalabad, 38000, Pakistan \\ ${ }^{4}$ Department of Life Sciences, Islamia University of Bahawalpur, 63100, Pakistan \\ Manuscript received on February 7, 2018; accepted for publication on April 12, 2018
}

\begin{abstract}
Broomrapes (Orobanche sp.) are root holoparasitic plants causing severe damage to various families of horticultural crops. A Preliminary survey was carried in tomato fields infested with orobanche in Potohar plateau of Pakistan. Results indicated that each planting bed comprising10-12 tomato plants contained 7-8 parasitic weeds. Overall survey indicated the $65-70 \%$ plants suffered partial or complete yield loss. Further, it was estimated that the number of weeds inhabiting plant ${ }^{-1}$ was ranged from 2-4. Yield loss was estimated at 57.17 tons/ha while in terms of financial loss, it was $2579.87 \$ /$ ha. Hence total estimated loss on the total surveyed area of 16 hectares was $41395.85 \$$. The high potential of tomato cultivation in Pakistan reinforces the urgent protection measures to resolve this emerging issue.
\end{abstract}

Key words: Broomrapes, Orobanche, Pakistan, tomato.

\section{INTRODUCTION}

Tomato (Solanum lycopersicum) is the second most important vegetable grown worldwide (Akhtar et al. 2010). The world processing tomato council (WPTC) has estimated the global tomato production being 37.1 million metric tons during 2018 , that is $2 \%$ less than that of the previous year (WPTC 2018). While, tomato production in Pakistan was 575923 tons, cultivated on 60,307 hectares during 2016 (FactFish 2018). Worldwide annual crop losses due to broomrape infestation are estimated at about $\$ 1.3$ to 2.6 billion. Egyptian

Correspondence to: Tanveer Ahmad

E-mail: tahmad@gudgk.edu.pk broomrape (Orobanche aegyptiaca) and branched broomrape (O. ramosa) only reported to infest about 2.6 million ha of solanaceous crops. These losses are mostly reported in Asia, Mediterranean area and North Africa (Joel et al. 2007, FernandezAparicio et al. 2009, Abbes et al. 2007).

Egyptian broomrape (O. aegyptiaca) is a dicotyledonous flowering plant (Joel et al. 2007) that is able to take carbohydrates from the phloem and water and minerals from the xylem of the host. Infection by Orobanche causes severe yield and quality losses (Lasur et al. 2017, FernandezAparicio et al. 2009). The main threat of this weed originates from its high multiplication rate and the longer viability in the soil (Abbes et al. 2007). 
The lack of resistance and a suitable control methods have seriously disturbed tomato cultivation in infested areas. A single plant of Orobanche can produce over 100,000 seeds which can survive in the field for up to 20 years (Gold et al. 1978); hence it is critical to highlight its current outbreak in Pakistan as future threat to tomato production. Rationale in the study is need for early measures to eliminate this parasite and strict quarantine measures are required to check its dispersal to other geographical areas. Although this weed has been previously reported in tomato in mid 70s in Balochistan province (Jafar and Shafique 1975), but rapid outbreak above the economic injury level was first reported in Potohar Plateau in north-eastern regions of Pakistan. The present study was aimed to assess the yield losses caused by $O$. aegyptiaca in tomato fields.

\section{MATERIALS AND METHODS}

\section{SURVEY}

A survey was conducted in the Katha Sukhral region of district Khushab. This area is intensively cultivated with tomato for commercial purposes. Data was recorded at fruiting stage of plants. Occurrence of Orobanche sp. was investigated on 16 hectares and divided into 10 sampling areas randomly. These areas were assigned with alphabetical codes viz. Area A, B, C, D... and so on. Tomato plants were transplanted on raised beds $2.5 \times 10$ feet. Plant to plant distance was $75 \mathrm{~cm}$ and bed to bed distance was $60 \mathrm{~cm}$. Each bed contained 10-12 tomato plants. Parasitic weeds (Orobanche sp.) were counted from 40 beds randomly selected from each sampling area (Fig. 1).

\section{IDENTIFICATION}

Orobanche species was identified as Orobanche aegyptiaca on the bases of botanical features. 20$30 \mathrm{~cm}$ Hight, the flowers normally over $20 \mathrm{~mm}$ long and anthers densely hairy. Keys and descriptions were taken from Parker and Riches (1993).

\section{NUMBER OF PARASITIC WEEDS PLANT ${ }^{-1}$}

The number of parasites was recorded on fruiting stage of the plants. Total number of parasites on each host plant was also determined randomly from sampling beds. Later, their means were calculated to compare the relative incidence of parasitic weeds among all sampling areas.

\section{FRESH WEIGHT OF HEALTHY AND INFECTED PLANTS}

Samples of healthy and infected plant were randomly collected (on fruiting stage) from the planting beds under experimental consideration. Their fresh weight was calculated in grams $(\mathrm{g})$.

\section{HEIGHT OF HEALTHY PLANT}

Height of healthy and infected plant was calculated at fruiting stage $(\mathrm{cm})$.

\section{FRESH WEIGHT OF WEED}

Fresh weight gained by an associated parasitic weed was calculated by carefully isolating from host plant in grams $(\mathrm{g})$.

\section{ASSESSMENT OF ECONOMIC LOSS}

The plant population was determined by the following formula,

Plant population $=\frac{43560}{(\mathrm{RxR})(\mathrm{PxP})}$

Where

43560 square feet is area of one acre.

$\mathrm{RxR}=$ Row to row distance (feet.)

$\mathrm{PxP}=$ Plant to plant distance in (feet.)

The plant population thus obtained was further used to estimate the economic loss by multiplying with yield/plant and rates (per $\mathrm{Kg}$ ) of tomato in wholesale market.

\section{RESULTS}

Infected plants generally showed the symptoms resembling to that of viral attack and mineral 


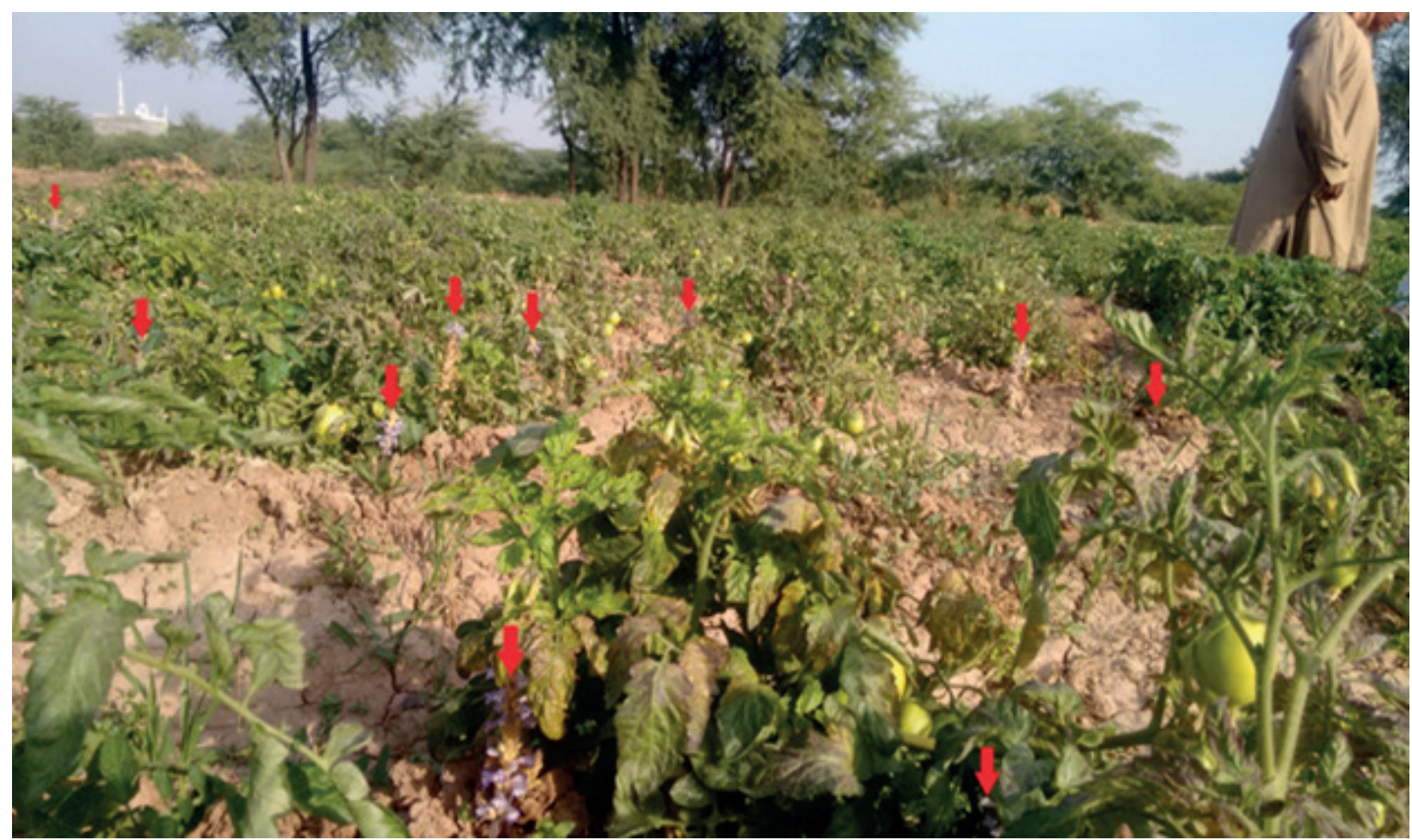

Figure 1 - Orobanche aegyptiaca in tomato fields in Pakistan.

deficiency. Host plants showed stunted growth and brittle leaves with distorted veins. The leaf color was yellowish to purple or both; perhaps due to reduced ability of nutrient uptake. Plant showed bushy appearance. Fruit formation does not occur in early stage of attack. If infestation occurs at fruiting stage, whole plant died with zero yields.

Survey has indicated that each planting bed was contaminated with 3-23 parasitic weeds. However, statistical conclusion summarizes that Orobanche sp. sprouted homogeneously (7-8) in all sampling areas under consideration. The number of parasites infesting a single host plant ranged from 2-5. All surveyed areas demonstrated higher infestation and yield loss (Table I).

Generally, it was noticed that fresh weight of healthy plants was more than $400 \mathrm{~g}$, while that of infected plants was less than $200 \mathrm{~g}$. Overall comparative weight of the fresh and infected tomato plants revealed $65-70 \%$ differences.
According to the results weight of parasitic weed ranged from 9.98-13.75 grams each. This data was collected by randomly selecting the growing weeds on experimental units (Table I).

\section{DISCUSSION}

In the current study, the losses and infestation of $O$. agyeptica were estimated by determining the number of parasites on each plant and over each planting bed. Previous studies to measure the levels of infection of broomrape on tomato were mainly based on total weight of broomrapes per host plant, height of the parasitic shoots, number of broomrapes per unit of grown surface, rate of broomrape reproduction, etc. (Cubero 1991, Rubiales et al. 2003). However, current methodology (based upon total number of parasites per host plant) has been more precise and conducted on wide scales (Gil et al. 1987, Cubero 1991).

In the present study, weight and the number of parasitic plant have been found parallel to 
TABLE I

Occurrence and loss of Orobanche aegyptiaca in Potohar plateau of Pakistan.

\begin{tabular}{|c|c|c|c|c|c|c|}
\hline $\begin{array}{l}\text { Sampling } \\
\text { areas }\end{array}$ & $\begin{array}{c}\text { No. of } \\
\text { Parasites/ } \\
\text { Planting bed }\end{array}$ & $\begin{array}{l}\text { No. of } \\
\text { parasites } \\
\text { Plant }^{-1}\end{array}$ & $\begin{array}{l}\text { Weight } \\
\text { of single } \\
\text { parasitic } \\
\text { weed (g) }\end{array}$ & $\begin{array}{l}\text { Fresh weight of } \\
\text { healthy plants (g) }\end{array}$ & $\begin{array}{l}\text { Fresh weight of } \\
\text { infected plants (g) }\end{array}$ & $\%$ loss \\
\hline A & $8.0 \mathrm{a}$ & $3.8 \mathrm{a}$ & $12.38 \mathrm{a}$ & $455.70 \mathrm{a}$ & $147.50 \mathrm{ab}$ & 67.63 \\
\hline B & $8.3 \mathrm{a}$ & $2.6 \mathrm{a}$ & $13.61 \mathrm{a}$ & $445.10 \mathrm{a}$ & $144.60 \mathrm{ab}$ & 67.51 \\
\hline $\mathrm{C}$ & $7.8 \mathrm{a}$ & $3.8 \mathrm{a}$ & $11.90 \mathrm{a}$ & $455.80 \mathrm{a}$ & $142.00 \mathrm{ab}$ & 68.84 \\
\hline $\mathrm{D}$ & $7.6 \mathrm{a}$ & $3.7 \mathrm{a}$ & $12.11 \mathrm{a}$ & $453.80 \mathrm{a}$ & $152.60 \mathrm{ab}$ & 66.37 \\
\hline $\mathrm{E}$ & $8.7 \mathrm{a}$ & $4.3 \mathrm{a}$ & $13.75 \mathrm{a}$ & $443.90 \mathrm{a}$ & $142.60 \mathrm{ab}$ & 67.87 \\
\hline $\mathrm{F}$ & $8.8 \mathrm{a}$ & $3.8 \mathrm{a}$ & $09.98 \mathrm{a}$ & $462.00 \mathrm{a}$ & $144.90 \mathrm{ab}$ & 68.63 \\
\hline G & $8.9 \mathrm{a}$ & $4.5 \mathrm{a}$ & $10.98 \mathrm{a}$ & $457.10 \mathrm{a}$ & $159.90 \mathrm{a}$ & 65.01 \\
\hline $\mathrm{H}$ & $8.6 \mathrm{a}$ & $4.1 \mathrm{a}$ & $12.07 \mathrm{a}$ & $504.40 \mathrm{a}$ & $157.20 \mathrm{ab}$ & 68.83 \\
\hline I & $7.7 \mathrm{a}$ & $4.5 \mathrm{a}$ & $12.26 \mathrm{a}$ & $457.10 \mathrm{a}$ & $143.20 \mathrm{ab}$ & 68.67 \\
\hline $\mathrm{J}$ & $7.3 \mathrm{a}$ & $3.5 \mathrm{a}$ & $12.11 \mathrm{a}$ & $446.90 \mathrm{a}$ & $134.70 \mathrm{~b}$ & 69.85 \\
\hline
\end{tabular}

each other. It indicated the close relationship with the losses imparted by them. Our results are in contrary to Sawafta (2012) where it is indicated that indices based on size and weight of broomrapes can be misleading. The possible reason for this phenomenon could be the less amount of attachments and the bigger size of the parasitic weeds. However current experiment was solely based on a field survey on susceptible tomato cultivar planted on a vast geographical area under natural conditions.

The present study indicated wide differences in the fresh weight of infected and healthy tomato plants. Earlier studies on tomato also support our conclusion where susceptible cultivars have reduced $94 \%$ shoot weight and $80 \%$ root weight. Similarly, yield loss was $65-70 \%$ in the whole area. However, infected plants have been previously reported to reduce the yield up to $90 \%$ (Sawafta 2012).

\section{REFERENCES}

ABBES Z ET AL. 2007. Field evaluation of the resistance of some faba bean (Vicia faba L.) genotypes to the parasitic weed Orobanche foetida Poiret. Crop Protec 26: $1777-$ 1784.

AKHTAR KP, SALEEM MY, ASGHAR M, AHMAD M AND SARWAR N. 2010. Resistance of Solanum species to Cucumber mosaic virus subgroup IA and its vector Myzus persicae. Eur J Plant Pathol 128(4): 435-450. https://link. springer.com/article/10.1007/s10658-010-9670-5.

CUBERO JI. 1991. Breeding for resistance to Orobanche species: A review. In: Wegmann $\mathrm{K}$ and Musselmann LJ (Eds), Progress in Orobanche Research. Proceeding of the International Workshop on Orobanche Research, Obermarchtal, p. 257-277.

FACTFISH. 2018. Pakistan: Tomatoes, production quantity (tons). Available online at [http://www.factfish. $\mathrm{com} /$ statistic-country/pakistan/tomatoes $\% 2 \mathrm{C} \% 20$ production $\% 20$ quantity]

FERNANDEZ-APARICIO M, SILLERO JC AND RUBIALES D. 2009. Resistance to broomrape species (Orobanche spp.) in common vetch (Vicia sativa L.). Crop Protec 28: 7-12.

GIL J, MARTIN LM AND CUBERO JI. 1987. Genetics of Resistance in Vicia sativa L. to Orobanche crenata Forsk. Plant Breeding 99: 134-143.

GOLD AH, DUANFOLA T, WILHELM S, SAGEN J AND CHUN D. 1978. Condition affecting germination of Orobanche vamosa L. Proceedings of the 3rd International Congress of Pathology, Munich, 190 p.

JAFAR H AND SHAFIQUE M. 1975. Some new records of hosts of Orobanche aegyptiaca L. in Baluchistan. Agric Pak 26: 519-520. 
JOEL DM ET AL. 2007. Biology and management of weedy root parasites. In: Janick J (Ed), Horti rev New York: J Wiley \& Sons, New York, USA, p. 267-350.

LASUR KL, LAHAV T, ABU-NASSAR J, ACHDARI G, SALAMI R, FREILICH S AND ALY R. 2017. HostParasite-Bacteria Triangle: The Microbiome of the Parasitic Weed Phelipanche aegyptiaca and TomatoSolanum lycopersicum (Mill.) as a Host. Front Plant Sci 8: 269.

PARKER C AND RICHES CR. 1993. Parasitic Weeds of the World: Biology and Control. Wallingford, UK, CAB International, $332 \mathrm{p}$.
RUBIALES D, PEREZ-DE-LUQUE A, CUBERO JI AND SILLERO JC. 2003. Crenate broomrape (Orobanche crenata) infection in field pea cultivars. Crop Prot 22: 865872.

SAWAFTA MS. 2012. Resistance of Some Tomato Species to Orobanche aegyptiaca (Comparative study). Master's thesis. Faculty of Graduate Studies, An-Najah National University, Nablus, Palestine.

WPTC. 2018. WPTC 2018 global estimate currently stands at 37.1 million metric tonnes. Available online at [http:// www.tomatonews.com/en/wptc-2018-global-estimatecurrently-stands-at-371-million-metric-tonnes_2_284. html]. 